\title{
Apresentação do organizador
}

Neste volume da Revista Horizontes em que auxiliei no esforço editorial colocamos no ar a produção de uma amostra de diversos linguistas aplicados brasileiros e estrangeiros em nove artigos originais voltados para o ensino de línguas e formação de professores para produzir esse ensino. Os artigos estão distribuídos da seguinte maneira em categorias organizadas de modo decrescente das mais numerosas para as menos: três artigos sobre a aula em sala de aula, dois artigos sobre formação de professores de línguas, dois artigos sobre o grande plano das ideias no ensino de línguas, um artigo sobre contrastes culturais entre brasileiros e espanhóis e um artigo sobre a produção de redações em português no vestibular por alunos oriundos do ensino médio.

O meio digital em que trafega agora a Revista Horizontes de Linguística Aplicada se incumbe de levar essa produção a todos os rincões do planeta em que se possa ler m português. Ao textos aqui publicados resultam muitos deles de trabalho de pesquisa produzidos no interior de programas nacionais de formação pós-graduada sob a orientação de professores orientadores mais experientes na condução da investigação e alguns aqui apresentados em co-autoria sob o signo da parceria estreita que esse trabalho de formação científica impõe. Dois dos trabalhos publicados refletem uma importante decisão de pesquisa analítica teórica de importantes aspectos do grande e mais elevado plano das ideias para a aquisição e o ensino de línguas. Estou tomando como ponto pacífico que todos os trabalhos aqui incluídos com arbitragem meticulosa se inserem na área acadêmico-profissional de Aquisição/Aprendizagem e Ensino de Línguas (AELin). Essa área precisa ser reconhecida como tal para saibamos a todo momento a que monta a teoria de que necessitamos e vamos acumulando no esforço de cientificidade que instauramos no Brasil com os dois livros teóricos pioneiros nessa perspectiva por Maria Junqueira Schmidt e Fernando Carneiro Leão em 1935.

A área de AELin se inscreve no âmbito mais alto, generalizante, da Linguística Aplicada, focada nos resultados teorizadores de pesquisa aplicada praticada não só nessa área, mas nas laterais da Tradução, da Lexicografia Aplicada, das Relações Sociais Mediadas pela Linguagem, entre outras. Ao nível da Linguística Aplicada é que ocorrem as produções científicas das duas disciplinas irmãs, a saber, a Linguística Geral e a Literatura (ou Estética da Linguagem, se a quisermos mais ampla e atual). A grande 
área mãe nessa perspectiva de alçamento a planos mais altos, abrangentes e de generalização abstrata é a Linguagem ou a Grande área da Linguagem na qual os fenômenos todos da linguagem encontrariam guarida teórica orgânica.

Neste número da Revista Horizontes, a categoria de tema mais exercitada é a do funcionamento do processo de ensino de línguas situado especificamente no seu palco mais visível e ativo da sala de aula no evento mais celebrado de intervenção que é a aula. Essa pesquisa aplicada situada na sala de aula de línguas teve seu início no Brasil no final dos anos 80 inspirada no exemplo engajado dos círculos de cultura e alfabetização de Paulo Freire no nordeste brasileiro nos anos 60, na pesquisa desbravadora de Roger Brown nos anos 70 sobre a aquisição da fala observando infantes desde o berço e nas análises de aulas gravadas e transcritas que conhecemos no Brasil pela ótica de pesquisa etnográfica de pesquisadores em educação como Frederick Erikson nos anos 80 que atuou como pesquisador convidado residente na primeira fase do Programa de PósGraduação em Linguística Aplicada da Unicamp.

Nesta edição a aula é estudada nas perspectivas da interação apoiada em andaimes com adoslecentes desvelando a importância do assunto interessante e/ou relevante que pode arrebatar o pós-púbere para o lado construtivo da interação que faz adquirir uma nova língua na escola (Edcléia Aparecida Basso e Fernando Silvério de Lima), na negociação de imagens e uso de estratégias de comunicação na sala (Poliana Pimentel Silva e Roseanne Rocha Tavares) e na qualidade (ainda aquém do que esperamos) das interações flagradas numa sala de ensino de inglês no ensino fundamental (Andreza Jesus Meireles e eu mesmo, José Carlos P. Almeida Filho).

Depois, encontramos dois artigos sobre formação de professores, que se constitui como uma das linhas de pesquisa do Programa de Linguística Aplicada da Universidade de Brasília: o estudo do retorno oferecido a estagiários que planejam aulas juntos e depois são observados fazendo sua parte de ensino (Barbra Sabota) que traz consciência promissora reconhecendo que o planejar está muito adiante do ensinar, e a importante análise de um conjunto de três programas de Licenciatura Letras de uma mesma Universidade atuando fora do seu tempo (Enrique Huelva Unternbäumen e Ana Carolina Nunes Araújo).

Outra categoria com duas contribuições de pesquisa analítico-teórica traz o aquilatamento do impacto do pós-modernismo no ensino contemporâneo de línguas (Mariana Rosa Mastrella) e uma resenha crítica do fenômeno do bilinguismo e suas facetas teórico-políticas hoje (Heloísa Augusta Brito de Mello). 
Por último, dois estudos esparsos estão incluídos que tratam de questões de redação de vestibular em língua materna (Cristiane Carvalho de Paula Brito) e do contraste cultural entre tópicos sócio-pragmáticos do Português brasileiro e Espanhol ibérico (Marta Giralt Lorenz). A busca por compreender o fenômeno múltiplo e complexo de aprender e ensinar línguas é que serve de substrato motivacional para os autores contribuidores. Quem ganha com esse esforço dos autores é a ciência de AELin, a Linguística Aplicada nessa vertente educacional e são os leitores da Horizontes que têm sede de conhecimentos específicos sobre os processos imbricados de aprender e de ensinar línguas vividos por alunos e professores, mas repercutidos de modo significativo, e ainda pouco conhecido, por terceiros agentes como diretores, secretários e ministros de educação, pais de alunos, jornalistas e autores de materiais didáticos, entre tantos outros.

José Carlos Paes de Almeida Filho Organizador convidado 